\title{
New Developments of Business English from ESP in China*
}

\author{
Wenzhong Zhu \\ School of English for International Business, Guangdong University of Foreign Studies, Guangzhou, China \\ Email: wenzhong8988@sina.com \\ Chuan Peng \\ School of English for International Business, Guangdong University of Foreign Studies, Guangzhou, China \\ Lingling Zhang \\ School of English for International Business, Guangdong University of Foreign Studies, Guangzhou, China
}

Xuefei Yi

School of English for International Business, Guangdong University of Foreign Studies, Guangzhou, China

\begin{abstract}
In recent years, researchers have made ongoing researches into the new development of business English as a sub-branch of ESP in China since the Ministry of Education approved business English as a formalized new discipline in 2007. The paper, through review and reflection into the findings of the previous researchers and the practices of business English in Guangdong University of Foreign Studies and other institutions, has concluded that the implication of business English in China has been broadened because it has evolved into a new discipline as a revolution in linguistics, and business English, as a comprehensive inter-discipline developed from ESP, is now faced with some new developments in China in areas such as disciplinary development, course design, teaching approach, teaching staff development, and student evaluation system.
\end{abstract}

Index Terms—ESP, business English, new development, China

\section{INTRODUCTION}

In the West, in the middle 1900s, linguistics changed silently in the wave of economic and social changes, during which researchers stated to concentrate their research focus on the application of languages in various contexts rather than on the regulation of language usages. At this period, ESP, namely English for Special Purpose, came into being with EST (English for Science and Technology) as an area of its activity. Contemporary business English originates from the Western countries in this era as a sub-branch of the so-called ESP described as a revolution of linguistics (Hutchinson \& Waters, 1987; Ellis \& Johnson, 1994). It is also a special branch of learning appearing in the background of economic globalization and trade internationalization. Currently, business English is becoming more and more important in academic position and has become the sub-branch of ESP with the fasted development. For example, in the UK, many series of business English books such as BEC and Market Leader, have been widely published and applied in countries like China today.

In China, business English can be traced back to the earliest era of 1950s, when high education institutions started to set the course of Foreign Trade English which mainly included such core courses as English electronic communication, selected readings of the Western paper, and oral English of foreign trade, etc. In 1990s, going along with the globalization of Chinese economy and the rapid increase of foreign trade volume, talents of business English had become increasingly welcome by the society. As a result, business English began to replace foreign trade English. For example, in Guangdong University of Foreign Studies, a new school called the School of English for Business specializing in teaching business English undergraduate and postgraduate programs was established with the integration of teachers from Faculty of English Language and Culture, School of Law, and School of International Trade and Economics.

At present, business English in China is highly recognized in the society as one of the most popular disciplines rather than an approach to learning English. Statistics shows that the number of universities that have opened business English major courses exceeds 800, and the schooling levels, majors and degrees are more and more diversified. For example,

\footnotetext{
* Note: The research is a partial achievement for the 2009 Research Program "Research on the Innovation and Development of the Teaching Mode of Business English Major" sponsored by the Subjects of the Social Science for the Outline of the Eleventh Five-Year Plan in Guangdong Province (Approval No. 09GK-02) and for the 2010 Research Program "Research on the Construction of A Curriculum Design System for Business English Postgraduate Program” sponsored by Guangdong Province Academic Degree and Postgraduate Student Committee(Approval No. 10JGXM-ZC06).
} 
in Guangdong University of Foreign Studies, there are already five undergraduate programs and four postgraduate programs. Graduates of business English are very popular in MNCs and other international business enterprises.

This paper summarizes and reflects on the specific new developments of business English from ESP in China from the aspects including status of disciplinary development, course design, teaching approach, teaching staff development, and student evaluation system, hoping to achieve some new perspectives for the better development of it in China and to offer some references to its development in other countries.

\section{NEW DEVELOPMENTS OF BUSINESS ENGLISH FROM ESP IN CHINA}

The new developments of business English from ESP in China include the status of disciplinary development, course design, teaching approach, teaching staff development, and student evaluation system, which are seen as follows:

\section{A. Disciplinary Development}

In China today, Business English evolving from ESP has developed into a formalized discipline from the concept of register analysis in recent years, which forms a brand-new innovative way to the development of ESP different from other countries (See Table 1).

TABLE 1

ROUTE OF DISCIPLINARY DEVELOPMENT OF BUSINESS ENGLISH AS A SUB-BRANCH IN CHINA

\begin{tabular}{|l|l|l|l|l|l|l|}
\hline Stage 1 & Stage 2 & Stage 3 & Stage 4 & Stage 5 & Stage 6 & Stage 7 \\
\hline $\begin{array}{l}\text { Register } \\
\text { analysis }\end{array}$ & $\begin{array}{l}\text { Discourse } \\
\text { analysis }\end{array}$ & $\begin{array}{l}\text { Target situation } \\
\text { analysis }\end{array}$ & $\begin{array}{l}\text { Skills and } \\
\text { strategies Analysis }\end{array}$ & $\begin{array}{l}\text { Learning-centred } \\
\text { approach }\end{array}$ & $\begin{array}{l}\text { Business } \\
\text { English major }\end{array}$ & $\begin{array}{l}\text { Business English } \\
\text { discipline }\end{array}$ \\
\hline
\end{tabular}

In general, Business English evolving from ESP has a development history of over 50 years through 7 stages in China. The first stage occurring in 1960's is called register analysis, with Halliday (1964) as its representative researcher, emphasizing on the identification of grammatical and lexical features of technical or engineering English.

The second stage occurring in 1970's is called discourse analysis, with Winddowson $(1974,1978)$ as one of the representative researchers, emphasizing on the development of a knowledge of how sentences are used in the performance of different communicative acts.

The third stage occurring in the late 1970's is called target situation analysis, with Munby (1978) as one of the representative researchers, emphasizing on the procedures for relating language analysis more closely to learners' reasons or needs for learning in communicative method, content, course design, etc. The forth stage occurring in the early 1980s is called skills and strategy analysis, with Grellet, F. (1981) and many others as its representative researches, assuming the idea that the application of languages has a similar thinking and interpreting process.

The fifth stage occurring in the late 1980s is called learning-centered approach, with Hutchinson \& Waters (1987) as the major representative, emphasizing on the understanding of language learning process, namely regarding ESP as a teaching approach or a systematic project including curriculum design, teaching planning, teaching material selection, teaching organization, and supervision and test on the learning process.

The fifth stage and the sixth stage are the stages happening in China as the brand new developments of Business English which are the major focus of the intend research. The fifth stage starting from the 1990s or even a little earlier era in China is named as Business English major in universities rather than perspective of academic studies in ESP. This stage occurs as a result of the needs for cultivating more Business English talents in line with the country's rapid development of international trade and economics after the opening-up policy. Its main focus is on how to develop and educate more competitive college students or trainees with a dual purpose of good language proficiency and good specialty knowledge in business fields by setting up necessary major courses, curriculum designs and teaching practices under the discipline of linguistics and applied linguistics.

The sixth stage occurring in the early 2000, to be exact in 2007, is named as Business English discipline, emphasizing on the formation of a completely new disciplinary theory and the establishment of a separate disciplinary system from the past applied linguistics, which constitutes the unique development route different from any other country. Well-known scholars, for instance, Chen Zhunming, Lin Tainhu (2006) and Wong Fengxiang (2009), etc., argue that Business English in China has become a new cross-discipline which applies theories and methods of linguistics, culture studies, management theory, economics to research on the phenomenon of linguistics and culture in international communication activities and to describe and interpret the features of English language and cultural factors used by people.

\section{B. Course Design}

The course design for the newly approved discipline of Business English in China has developed with different characteristics from traditional ESP as a result of their differences in teaching or learning objectives. For instance, Business English, compared with ESP, has a more extensive or broader teaching goal such as allowing learners to understand and master basic business theories, business environment and business terms related to business world while ESP is limited to the study of English language knowledge in a particular sector or industry context such as chemistry, medicine or tourism. Due to the different teaching or learning objectives, the courses of Business English for undergraduate or postgraduate programs has been designed with a general principle of approximately $70 \%$ English 
language courses and $30 \%$ courses of business theories and practices such as Introduction to Business, Introduction to Economics, International Trade, Business Communication, International Finance, International settlement, etc.

The modular course design for Business English major is usually allocated with a total credit of 2800 teaching hours, with the first year concentrating on the study of English language knowledge for the preparation of a sound language foundation for the future study of business theories and practices in English. In the second year, the courses are still mostly designed with English language knowledge, but some basic business courses like Introduction to Business are also arranged in order to pave a foundation for learning more complicated business courses. In the third year, the major courses are business ones with very few language courses left. These courses are mainly selective ones for learners to choose according to their interests. In the forth year, there are still some business courses left for selection in the first semester but only dissertation writing is left for learners in the second semester.

\section{Teaching Approach}

Teaching business courses in English or bilingual language has become the main mode of Business English teaching in Chinese universities. Teaching business courses in English means that English is used in the whole procedure of teaching, including PPT arrangement, lecturing, research report, assignment, case study, test, question and answer, but at the same local language may also used to explain some key terms, concepts and difficult points (Zhu, 2004). Of course, teaching business courses in English is different from teaching business courses in bilingual languages, but we can also say that teaching business courses in English is a senior form of teaching business courses in bilingual languages. In China, bilingual teaching refers to the mode of teaching with English and Chinese used simultaneously, which normally requires that English should be used in on the board, but partial English and partial Chinese should be used. Both single English teaching (or English-instructed teaching) and bilingual teaching have one thing in common, which is the textbook used in the teaching must be textbooks introduced from foreign countries or comprised by Chinese professors. In fact, as a result of the fact that single English teaching, which may be accompanied by Chinese explanation of difficulty points, the difference between single English teaching and bilingual teaching tends to be smaller and smaller in China.

In addition, other teaching methods are also becoming more and more popular in business English teaching, for example, simulation teaching, task teaching, interactive teaching, etc. These teaching methods can be very applicable in business English teaching as a result of its dual roles of the teaching, namely improving students' English language abilities and business knowledge and skills.

\section{Teaching Staff Development}

Teachers of business English should possess unique features of multi-skills as a main development trend in China today. These multi-skilled teachers or professors of business English must be proficient in English language and well-developed in a certain field of business study so as to well teach a certain type of business course in English. Such a type of multi-skilled teacher team can be divided into three basic categories including (Refer to Table 2): (1) teachers of English major + business management major who can teach both English courses and business management courses and conduct academic researches in both the fields of study; (2) teachers of English major + fairly good business management knowledge base ho can mainly teach English courses and conduct academic researches mainly in the linguistic field of study; (3) teachers of business management major + fairly good English language base who can mainly teach business management courses in English, and conduct academic researches mainly in the field of business management. In addition, this types of teachers of business English are acquired through various approaches such as sending teachers of English major to a foreign university to study for a master or doctor program in business management, recruiting teachers of two majors, recruiting foreign exports to teach business management courses, etc. Take School of English for International Business of Guangdong University of Foreign Studies as an example. Multi-skilled teachers who can teach business English courses in English account for about 30\% of the staff, business English teachers has two majors of English language and business management account for about 8\%, and what's more, over $58 \%$ staff have experiences of degree study or academic visiting research in foreign universities.

TABLE 2

THREE BASIC TYPES OF MULTI-SKILLED TEACHER TEAM PROFICIENT FOR BUSINESS ENGLISH IN CHINA

\begin{tabular}{|l|l|l|}
\hline No. & Type & Description of abilities \\
\hline 1 & $\begin{array}{l}\text { Teachers of English major }+ \\
\text { business management major }\end{array}$ & $\begin{array}{l}\text { This type of business English teachers has two majors, who can teach both } \\
\text { English courses and business management courses and conduct academic } \\
\text { researches in both the fields of study. }\end{array}$ \\
\hline 2 & $\begin{array}{l}\text { Teachers of English major + } \\
\text { fairly good business } \\
\text { management knowledge base }\end{array}$ & $\begin{array}{l}\text { This type of business English teachers has an English major, who can } \\
\text { mainly teach English courses and conduct academic researches mainly in } \\
\text { the linguistic field of study. }\end{array}$ \\
\hline 3 & $\begin{array}{l}\text { Teachers of business } \\
\text { management major + fairly } \\
\text { good English language base }\end{array}$ & $\begin{array}{l}\text { This type of business English teachers has a business management major, } \\
\text { who can mainly teach business management courses in English, and } \\
\text { conduct academic researches mainly in the field of business management. }\end{array}$ \\
\hline
\end{tabular}

\section{E. Student Evaluation System}

The existing evaluation system of Business English students' study performance is still under construction and 
perfection in China, which is currently a very special system still adopting the same system of CET (College English Test). CET is a national level English proficiency test including band-four and band-six for English major students, which can not distinguish the differences of Business English major from those of general English major. However, in recent years, as a supplementary method of evaluation, BEC Test and China Business English Certificate Test (Organized by China Association of International Trade) are also being used or developed to evaluate the study performance of Business English students at different levels. But a more perfected evaluation system for Business English students' abilities and study performance should be developed as soon as possible.

\section{CONCLUSION}

As a result of the six-stage development of business English as a sub-branch of ESP, since the Ministry of Education approved business English as a formalized new discipline in 2007, Business English in China has been highly recognized in the society as one of the most popular disciplines rather than an approach to learning English. The paper, through review and reflection into the findings of the previous researchers and the practices of business English in Guangdong University of Foreign Studies and other institutions, concludes that the implication of business English in China has been broadened because it has evolved into a new discipline as a revolution in linguistics, and business English, as a comprehensive inter-discipline developed from ESP, is now faced with some new developments in China in areas such as disciplinary development, course design, teaching approach, teaching staff development, and student evaluation system.

In disciplinary development, Business English in China has become a new cross-discipline which applies theories and methods of linguistics, culture studies, management theory, economics to research on the phenomenon of linguistics and culture in international communication activities and to describe and interpret the features of English language and cultural factors used by people. In course design, Business English in China has developed with different characteristics from traditional ESP as a result of their differences in teaching or learning objectives. In teaching approach, teaching business courses in English or bilingual language has become the main mode of Business English teaching in Chinese universities. In teaching staff development, teachers of Business English should possess unique features of multi-skills as a main development trend in China today, and these multi-skilled teachers or professors of business English who can be divided into three basic categories must be proficient in English language and well-developed in a certain field of business study so as to well teach a certain type of business course in English. In student evaluation system, Business English students are now tested by using the same system of CET (College English Test). But supplementary methods of evaluation are also developed and applied in recent years.

\section{REFERENCES}

[1] Ellis, M. \& Johnson, C. (1994). Teaching Business English. Oxford University Press, 4-220.

[2] François Grin. (1994). The Economics of Language: Match or Mismatch? International Political Science Review, 1994: Vol. 15, No. 1, 25-42

[3] Halliday, M.A.K., et al. (1964). The Linguistic Sciences and Language Teaching. Longman.

[4] Hutchinson, T. \& Waters, A. (1987). English for Specific Purpose. Cambridge University Press.

[5] Inhelder, B. and Piaget, J. (1958). The Growth of Logical Thinking from Childhood to Adolescence. New York: Basic Books.

[6] Lin Tianhu. (2005). To strengthen Theory Construction is the Key to the Ongoing Development of Business English Discipline. International Business Research.

[7] Mundby, J. (1978). Communicative Syllabus Design. Cambridge University Pres.

[8] Mo Zaishu, et al. (2006). Research on Business English Based on Linguistic Economics. Journal of Hunan University.

[9] Widdowson, H.G. (1978). Teaching Language as Communication. Oxford University Press.

[10] Wong Fengxiang. (2009). Business English Research. Shanghai Jiao Tong University Press.

[11] Zhu Wenzhong. (2005). Investigation and Reflection into the Mode of Teaching Business English Major in English. Journal of International Trade and Economics Research.

[12] Zhu Wenzhong. (2006). A New Perspective of the Concept and Development Trend of Business English in Higher Education Institutions. International Education Studies.

[13] Zhu Wenzhong. (2008). On Differences between General English Teaching and Business English Teaching. English Language Teaching.

Wenzhong Zhu was born in Henan, China, in 1964. He received his NBA degree from Southampton University, UK, in 2001, and his $\mathrm{PhD}$ degree in business management from Sun Yat-sen University, China, in 2008. He is currently professor in School of English for International Business, Guangdong University of Foreign Studies, China. He has significant achievements in the business English teaching and research in recent years. For example, the course "Introduction to Contemporary Business" taught by him was awarded as the national model course of bilingual teaching sponsored by Department of Education of P.R. China, in 2009, and in addition, he has got a number of business English books published in the press in recent years. 
Chuan Peng whose major is business English studies is currently postgraduate students of School of English for International Business, Guangdong University of Foreign Studies, China.

Lingling Zhang whose major is business English studies is currently a postgraduate student of School of English for International Business, Guangdong University of Foreign Studies, China.

Xuefei Yi whose major is business English studies is currently a postgraduate student of School of English for International Business, Guangdong University of Foreign Studies, China. 